\title{
Interorganizational Cost Management Study on Inhibitor
}

\author{
Rafael Araújo Sousa Farias ${ }^{1}$ \\ ${ }^{1}$ Department of Accounting Sciences, Federal University of Santa Catarina, Florianópolis, Brazil. \\ Correspondence: Rafael Araújo Sousa Farias, Universidade Federal de Santa Catarina, Centro Socioeconômico, \\ Bloco F, Campus Universitário: Trindade - CEP 88.040-970 - Florianópolis, Santa Catarina, Brasil. E-mail: \\ farias-rafael@ hotmail.com
}

Received: December 21, 2015

Accepted: January 17, 2016

Online Published: February 25, 2016

doi: 10.5539/ibr.v9n3p68

URL: http://dx.doi.org/10.5539/ibr.v9n3p68

\begin{abstract}
Strategic cost management in supply chains is not a new concept. Coordinated actions between companies of the same chain, in order to reduce costs and end consumer price, offer opportunities for improved results. Interorganizational Cost Management (IOCM) is a structured approach with a broad vision, beyond the borders of the organization, which aims to reduce costs at the internal and external levels. Indeed, cost management is a complex issue that permeates all areas of the organization and may pose a number of difficulties to be implemented and sustained. Thus, this work has the overall goal of identifying, in the literature, the factors and conditions that inhibit the applicability of the Interorganizational Cost Management approach. To achieve these goals, an analysis was made of 35 academic research studies available in the literature that reported the difficulties faced by companies in cooperative cost management. The analysis of the studies showed the perceptions of different companies, and described the difficulties they face; therefore, the present research is qualitative and exploratory. Factors that inhibit IOMC were grouped into: (i) corporate strategy; (ii) integration of companies; (iii) people; (iv) intra- and interorganizational processes; (v) corporate training and education; (vi) disputes between companies; and (vii) lack of trust between companies.
\end{abstract}

Keywords: interorganizational, cost management, inhibitors, supply chain

\section{Introduction}

The evolution of markets and the increasing complexity in supply chains led to the emergence of new management techniques and new information exchange systems between companies, going through the internal environment and achieving interorganizational relations (Kulmala, Paranko, \& Uusi-Rauva, 2002). Wincent (2008) stated that interorganizational networks emerged as an alternative to the needs of companies, and inter-relationship is the future trend. For Drucker (1997), it is up to companies to position themselves and articulate relationships that help them in their activities in order to face challenges (such as globalization) as an opportunity.

Companies can gain competitive advantage by Interorganizational Cost Management (IOCM), whose goal is to find solutions that have lower costs when compared to the sum of costs of companies acting individually (Kulmala et al., 2002). Cooper and Slagmulder (1999) explained that Interorganizational Cost Management is a structured approach to coordinate companies' activities in a supply chain, in order to reduce total network costs.

Studies about inter-relationship claim that this approach is a tool for companies to grow in the market where they operate, generating benefits for all parties involved (Borin \& Farris, 1990; Ellram, 1994; Ellram \& Siferd, 1998; Cooper \& Slagmulder, 1999; Ferrin \& Plank, 2002; Lalonde, 2003). However, from an empirical point of view, there are a number of companies which fail to participate in cooperative processes, and many networks are unable to consolidate their structures and management models (Pereira, Alves, \& Silva, 2010).

The analysis of the opinions of the cited authors shows that IOCM is as an opportunity in this scenario, but its application can be a difficult task. Additionally, given the advantages it offers, most companies would be expected to apply ICOM, but paradoxically, the opposite occurs (Kulmala et al., 2002).

Thus, as inter-relationships can provide benefits and competitiveness in the market, one may wonder why companies abandon partnerships, and what reasons lead to difficulties and subsequently, cause companies to break off these relationships. 
This situation is seen as a research opportunity; thus, the research question of the present study is: What are the factors or situations that inhibit the applicability of the Interorganizational Cost Management approach?

To answer the research question, the general objective of this study was to identify, in the literature, the factors and situations that inhibit the applicability of the Interorganizational Cost Management approach?

Studies that help companies to successfully implement interorganizational cost programs can generate benefits while increasing knowledge of business processes and related costs (Stapleton, Pati, Beach, \& Julmanichoti, 2004). In fact, the diagnosis of the reasons why inter-relationships fail can contribute at every stage of the relationships, as it emphasizes their importance at the early stages, and enables an analysis of whether a company has many factors that inhibit relationships with other companies in their supply chains.

Pereira et al. (2010) explained that this initial analysis can assist managers in establishing the company's by-laws, entering into contracts and selecting members of the chain (especially suppliers); it may even preclude the entry of any member to avoid further problems, which could cause distress between parties. For the authors, finding out the reasons why companies leave networks can mean an improvement in their management process.

Bastl, Grubic, Templar, Harrison, and Fan (2010) explained that managers are facing new challenges in the search for competitive advantage outside their organizations; however, they have little guidance about the potential challenges related to implementation of approaches to Interorganizational Cost Management. The authors explain that managers find it difficult to deal with the complexity of the problems that prevent organizations to obtain success in their cooperative actions.

\section{Theoretical Framework}

\subsection{Traditional Approaches of Accounting to Interorganizational Cost Management}

Functions that accounting should exercise for inter-organizational context are different from those carried out for only one company. Bastl et al. (2010) stated that traditional accounting practices often do not fulfill the role of managing inter-organizational relationships. Seal, Cullen, Dunlop, Berry, and Ahmed (1999) and Tomkins (2001) argued that accounting focused on inter-relationships should generate information that helps managers make decisions in this scenario. The information currently generated by accounting should cover not just one company but should consider the members of the chain that such company is a part of.

The Standard Cost, for example, can be recognized as an efficient accounting practice when applied by a company in its home environment. However, Gupta and Gunasekaran (2004) claimed that the Standard Cost does not encourage improvements in the supply chain.

\subsection{Forming Interorganizational Networks}

What motivates companies to form inter-organizational networks? Amato Neto (2000) stated that companies seek competitive advantages, e.g., the possibility of combining skills, using know-how of other enterprises, sharing the workload of carrying out technological research, sharing risks and costs of exploring new opportunities, sharing resources and strengthening the purchasing power.

In fact, the interest in forming strategic alliances must be accompanied by initial concerns about the protection of enterprises. Pereira et al. (2010) argued that the process of forming interorganizational networks requires, in most cases, enforcement mechanisms to assist in regulating the relationship between companies.

Janowicz-Panjaitan and Noorderhaven (2009) explained that these mechanisms are intended, among other purposes, to punish opportunistic behavior, and explained that the network must have rules, code of ethics and a committee that monitors compliance with the rules set out to participants.

Abbade (2005) pointed out that companies must take some action to protect themselves from opportunistic actions; for example, they should determine the role of each member of the chain, specifying their rights and obligations; they should protect their strategic resources that cannot be violated or disclosed, and learn about the history of the possible chain partners.

\subsection{Inter-Relationship Problems}

In transaction costs theory, Williamson (1985) explained that in a perfect scenario, which would be unreal, where there was no opportunism among members of a chain and information was available to all parts and at all times, failure in operations would not be very likely. Thus, the theory states that the fear of opportunistic behavior and the absence or lateness of information to the members of the chain creates the need for the network to establish strong mechanisms of control and to increase bureaucracy and complexity of transactions between its members. Williamson (1985) mentioned that the uncertainty as to the benefits and obligations allocated to each company of 
the network is considered as a factor that inhibits the interest of companies to enter into cooperative relations.

In fact, the literature states that companies can gain many benefits by coordinating efforts and acting collaboratively with members of the chain, and that there are many benefits offered to justify the formation of inter-organizational networks (Cooper \& Slagmulder, 1999). However, many problems can occur during this process, which can make it difficult or impossible to achieve the goals pursued by companies.

\section{Methodological Aspects}

First, the field of exploration was delimited, and the databases selected after these steps were followed: (I) the databases which appeared in the Portal de Periódicos Capes (501 databases) were selected; (ii) in the field "Knowledge Areas", the "Social Sciences" option was specified, and the sub-area "Business Administration-Public Administration-Accounting" was chosen, which resulted in 73 databases; (iii) the databases were selected to provide "Full Text" (24 databases); and (iv) a selection was made of the databases that allowed searches on "All text fields" and the use of at least two axes by using Boolean expressions. The process resulted in 13 databases: ANNUAL REVIEWS; CAMBRIDGE JOURNALS ONLINE; EMERALD INSIGHT; JSTOR; OECD LIBRARY; SAGE JOURNALS ONLINE; APA PSYCARTICLES; WILEY ONLINE LIBRARY; PROQUEST; WEB OF SCIENCE; SCIENCEDIRECT; SCOPUS; and EBSCO.

In the selected databases, searches were conducted with terms in English, using two axes. Axis 1 contained words whose meaning is similar to "inhibitor", i.e., those words that refer to the idea of "barrier", something that gets in the way or hinders. Axis 2 contained terms related to "inter-organizational cost management".

Searches were formulated with the following keywords combined with the axes: Axis 1-"inhibit *" OR "barrier *" OR "problem*" OR "disturb* "OR" difficult*." Axis 2-"interorganizational cost" OR "inter-organizational cost" OR "interorganisational cost" OR "inter-organisational cost".

The searches were conducted in January 2015, selecting the option "all text fields" using the Boolean operator "AND" between the axes, the Boolean operator "OR" between terms, without delimitation of time period.

The search was conducted in the 13 selected databases; however, there were search results in only seven databases (at least one article). The databases that provided the articles were EMERALD INSIGHT; WILEY ONLINE LIBRARY; PROQUEST; WEB OF SCIENCE; SCIENCEDIRECT; SCOPUS; and EBSCO. The search yielded a total of 418 results.

In order to ensure the relevance of the search results, the content was filtered through the following steps: (I) the 418 articles arising from the search were downloaded; however, only 225 articles were fully available and free; (ii) the 225 studies were imported into a bibliographic management software, Mendeley®, which was used to delete 134 repeated or misaligned studies, thus yielding 91 works; (iii) the titles and abstracts were read, and the articles that were not aligned with the search criteria were excluded. In order to be included, a study should: a) address the issue of cost management in the inter-organizational context; b) contribute to the debate about inhibitors and barriers to Interorganizational Cost Management. After filtering, 35 studies were selected to compose the bibliographic portfolio to be analyzed.

Then, the articles were fully read. The reading of each article identified the factors that hampered/hindered Interorganizational Cost Management in each environment, enabling the creation of a report with all the identified factors. Twenty-five factors inhibiting IOMC practices were identified and, in order to facilitate the discussion of the factors, they were grouped into related inhibiting factors: (i) corporate strategy; (ii) integration of companies; (iii) people; (iv) intra- and inter-organizational processes; (v) training and corporate education; (vi) disputes between companies; and (vii) lack of trust between companies.

\section{Results}

\subsection{Corporate Strategy}

Porter (1980) explained that "strategy" can be seen as building defenses against the competitive forces or as determining positions for the company to reach its goals. According to Porter (1980), strategy describes what is absolutely necessary to reach a goal, where the ultimate goal of an organization is fulfilling its mission to ensure business continuity.

The way organizations determine and execute their strategies decisively influences the way parties consider the balance and efficiency of cooperation and influences the motivation of organizations to continue or terminate cooperation over time (Guth, Schmittberger, \& Schwarze, 1982).

Table 1 shows the inhibitors relative to corporate strategy. 
Table 1. Inhibitors relative to corporate strategy

\begin{tabular}{ll}
\hline Inhibitors & Authors \\
\hline Differences between companies' strategic plans & Hitt, Dancin, Levitas, Arregle, and Borza (2000); Ojala and Hallikas (2007) \\
Lack of long-term management goals & Ferrin and Plank (2002); Möller, Windolph, and Isbruch (2011) \\
Imbalance between short-term and long-term gains & Pereira et al. (2010) \\
Loss of customer focus & Lin, Collins, and Su (2001); Himme (2012) \\
\hline
\end{tabular}

Source: Survey data (2015).

One of the barriers to the success of partnerships between companies is the difference between partners' strategies, that is, different reasons that led companies to enter into alliances. Understanding partners' goals and the compatibility with them, can improve the performance of partnerships, in that companies' characteristics and their individual goals play a significant role in building relationships (Ojala \& Hallikas, 2007; Hitt et al., 2000).

Ferrin and Plank (2002) explained that cost should be examined from a long-term perspective and argued that they should include other elements beyond the initial purchase price. Partner companies must signal, in a credible manner, their intentions to continue the relationship in the long run when deployment of IOCM is intended (Möller et al., 2011; Ferrin \& Plank, 2002).

The fact that partnerships are aimed at the long-term does not mean that the strategy of earning profits should be a long-term one. Pereira et al. (2010) explained that the imbalance between short-term and long-term gains can inhibit inter-relationships and be a point of tension for many relationships.

Lin et al. (2001) explained that companies cannot lose focus on their customers. According to the authors, they should devise their relations while targeting at customers as well as improve profit potential. However, managers may become overly attentive to cost-related issues, and possibly lose focus on customers. Himme (2012) stated that a strategic cost management plan requires a holistic vision in order to maintain focus on the customer, since, according to the author, work becomes useless when the customer-oriented vision is lost.

\subsection{Integration between Companies}

In the process of cooperation between companies, new features arise, such as increasing complexity and the need to work within and across organizational boundaries. Thus, the dynamics of the market requires companies to quickly share and integrate information. Companies should be able to dynamically communicate and analyze the processes taking place between them.

Table 2 shows inhibitors relative to integration between companies.

Table 2. Inhibitors relative to integration between companies

\begin{tabular}{ll}
\hline Inhibitors & Authors \\
\hline Difficulties in integrating information between companies & Ellram (2002); Ramos (2004); Mouritsen and Thrane (2006) \\
\hline
\end{tabular}

Source: Survey data (2015).

One factor that inhibits the success of cooperative relationships is the lack of cross-functional teams in companies. Procurement management (from buyers) and supply management (from suppliers) need specific support from cost management experts who are assigned to support these processes (Ellram, 2002).

The management of close relations between suppliers and buyers requires additional attention to supply chain issues and the inclusion of more data about the organization and the external environment. The relationship between the partner companies can hardly flow without the help of certain management technologies that, however imperfectly, help managers manage the relationships between partners (Ramos, 2004; Mouritsen \& Thrane, 2006).

\subsection{People}

The determination of corporate strategies should take into account the characteristics of the people involved in the change, the period during which this change is to be implemented, the depth of change and the desired duration of its effects (Lopes, Stadler, \& Kovaleski, 2003).

In fact, people may be prepared or ale to make changes that will occur when companies implement Interorganizational Cost Management.

Table 3 shows people-related inhibitors. 
Table 3. People-related inhibitors

\begin{tabular}{ll}
\hline Inhibitors & Authors \\
\hline $\begin{array}{l}\text { Resistance to change by members of organizations } \\
\text { Lack of management support from members of }\end{array}$ & Ellram (2002); Seal et al. (1999); Himme (2012) \\
organizations & \\
\hline
\end{tabular}

Source: Survey data (2015).

Axelsson et al. (2002) explained that the change in organizational behavior refers not only to the question of designing management systems, but it is a systemic effort. In order to achieve the organizational changes needed to allow companies to expand inter-relationships, they should observe how much people are interested in the changes, and whether or not this can be a barrier.

Ellram (1994) pointed out that the flexibility to change is an important factor for the successful implementation of management programs. Thus, changes in organizational culture can pose a double challenge, depending on the level of resistance of its employees and the complexity of the strategic cost management approach. Elrram and Siferd (1998) pointed out that when an organization attempts to make a change in its operations, the nature and extent of this change needs to be clearly defined.

The internal culture and organizational structure of the company should be characterized by the support of senior management for cost management purposes. In addition to resources that can support chain cost management, cross-functional teams should be encouraged to identify and implement cost management approaches. Those responsible for cost management are hampered when they receive support from members of the company (Seal et al., 1999; Ellram, 2002).

Himme (2012) explained that it is not enough for a company to have only the managers committed to reducing costs in the organization. The company should seek to develop and encourage its employees so that everyone adopts the cost-reduction philosophy. Himme (2012) also explained that the development of a corporate culture is a long-term process, and persistence is a prerequisite.

\subsection{Intra- and Interorganizational Processes}

The processes to be executed by the companies to act collaboratively can be a determining factor for the success of IOCM. The literature shows some factors that can inhibit Interorganizational Cost Management with regard to processes.

Table 4 shows the inhibitory factors relative to intra- and interorganizational processes.

Table 4. Inhibitors relative to intra- and interorganizational processes

\begin{tabular}{ll}
\hline Inhibitors & Authors \\
\hline Poorly prepared IOCM model design & Waeytens and Bruggeman (1994) \\
Highly complex IOCM systems & Kaplan and Anderson (2004) \\
Inflexibility in IOCM & Dubois (2003) \\
Lack of regular reviews of performance & Gareth(2005) \\
Management failure by dominant organization in the chain & Caker (2008); Carr and Ng (1995); Dekker (2003) \\
\hline
\end{tabular}

Source: Survey data (2015).

Waeytens and Bruggeman (1994) pointed out that problems in the design of the models of cost management can prevent companies from determining their costs correctly, and then they may have difficulty in collaborating with members of their chain. A complex model with poorly designed activities, without providing information on the actual cost of a company's activities, is seen as a barrier to IOCM.

Kaplan and Anderson (2004) warned that highly complex cost management models may inhibit their applicability. The authors explained that the models implemented by the companies tend to evolve while they learn about the variety and complexity of their processes, applications, suppliers and customers. According to Kaplan and Anderson (2004), with a view to increasing the precision and detail of information, the models may become overly complex, which can be a barrier to the operation of the chain.

According to Dubois (2003), when cost management is subject to interaction between buyers and suppliers, it is not possible to predetermine what should be included in the "total cost" of products or services, at the beginning of 
the relationship. The author explains that a predefined total cost could unnecessarily limit cost reduction opportunities.

Dubois (2003) explained that while there occurs joint management of costs, learning about cost behavior can occur, thus favoring continuous improvements. Thus, the idea of a default total cost for a model can bring problems due to the dynamic and changing needs of both partners.

Gareth (2005) stated that the alliances formed by companies that are too rigid or too flexible cannot achieve success. For the author, balance is the key to success; thus, partners should develop a relationship in which they are able to shape the changes occurring in the environment where they are situated without losing the necessary rigidity to keep the structure as agreed between the parties.

Gareth (2005) explained that relations between companies must undergo regular assessments, in order to make necessary adjustments so that companies can overcome the difficulties that will appear.

Caker (2008) pointed out that the ability of the dominant company to manage the chain is a key issue for the development of interorganizational relationships, a point of view shared by other authors (Carr \& $\mathrm{Ng}, 1995$; Dekker, 2003).

\subsection{Corporate Training and Education}

Bohlander, Snell, and Sherman (2003) explained that "training" is the effort made by the company to encourage the learning of their employees. Corporate training and education are part of an organization's activities to enable the development of skills that can make the individual able to perform their current and future roles (Borges-Andrade, 2002).

Table 5 shows the inhibiting factors relative to corporate training and education.

Table 5. Inhibitors relative to corporate training and education

\begin{tabular}{|c|c|}
\hline Inhibitors Factors & Authors \\
\hline $\begin{array}{l}\text { Lack of expertise and education programs } \\
\text { geared towards employees }\end{array}$ & $\begin{array}{l}\text { LaLonde and Pohlen (1996); Ramos (2004); Kulmala et al. (2002); Ellram (2002); Thomson } \\
\text { and Gurowka (2005); Himme (2012) }\end{array}$ \\
\hline Inconsistent taxonomies & Thomson and Gurowka (2005) \\
\hline Lack of understanding of costs along the chain & Nicolini, Tomkins, Holti, Oldman, and Smalley (2000) \\
\hline $\begin{array}{l}\text { Lack of perception of the value resulting from } \\
\text { the relationship }\end{array}$ & Cannon and Homburg (2001) \\
\hline
\end{tabular}

Source: Survey data (2015).

LaLonde and Pohlen (1996) explained that expertise can overcome many problems associated with cost-related activities across the boundaries of companies. For the authors, expertise can help in the process of Interorganizational Cost Managemen by, identifying the "ineffective" activities carried out by other companies.

Ramos (2004) explained that one of the barriers to the application of Interorganizational Cost Management approaches is the absence of competence on the part of business costs managers. The author stated that the close relations between suppliers and buyers require additional reports on the problems in supply chains and the need for more data on the organizations and the external environment.

Kulmala et al. (2002) stated that companies must assess whether or not supplier relationships are beneficial for their business. In this way, companies should be able to calculate the amount of cost reduction that relationships will offer; thus, there is a need to understand cost behavior of their products.

Education has been one of the most valuable tools in improving the performance of supply chain and cost management. Companies can create training programs for those involved, such as employees and suppliers, so that they can learn the concepts and principles of the inter-relationship (Ellram, 2002; Thomson \& Gurowka, 2005).

Himme (2012) explained that in order to reduce resistance to change and prepare employees for cost reduction programs, companies must provide training and education to describe the changes that may occur. For the author, it is critical that instructions are given before changes arise.

Thomson and Gurowka (2005) emphasized the importance of the taxonomy of terms used in cost management, as inconsistent and/or inexistent terminology and standards no can be a barrier for everyday relations between companies. The authors explained that partner companies should avoid noise in communication, and that training 
and education are fundamental capacitors to the success of any strategic cost methodology.

Nicolini et al. (2000) suggested that one of the barriers to Interorganizational Cost Management appears because companies often operate without a full understanding of costs along the supply chain. In general, companies develop projects and then quote for prices of suppliers who were not involved in project design development.

The companies analyze whether or not relationships will continue by observing the ability of such relationships to generate demonstrable value to the participants (Cannon \& Homburg, 2001). Indeed, the reduction of the total cost of the product available to the end consumer is an indicator of the efficiency of inter-organizational relationships, but it is not the only one. The lack of perceived value generated by the relationships between the companies is appointed by Cannon and Homburg (2001) as a factor that could impair the continuity of long-term relationships.

The measurement of the generated value or the intangible value resulting from the relations between the companies is a difficult task. Cannon and Homburg (2001) explained that, in order to create models to assess the generation of value, the researchers will need to resort to a variety of perspectives.

\subsection{Conflicts between Companies}

Cooper and Slagmulder (1999) explained that conflicts arising from relationships may be an impediment to achieving established goals between network partners. Indeed, conflicts and differences are factors that, according to literature, inhibit the IOCM practice.

Table 6 shows the inhibitory factors relative to conflicts between companies.

Table 6. Inhibitors relative to conflicts between companies

\begin{tabular}{ll}
\hline Inhibitors & Authors \\
\hline Uneven distribution of benefits & Kajüter and Kulmala (2005); Christopher (1998) \\
Difficulty in defining mutual benefits & Dekker (2003); Kajüter, Kulmala (2005) \\
Inability to determine market prices & Nicolini et al. (2000) \\
Constant conflicts & Arino and De La Torre (1998); Lui (2009) \\
Suppliers recognize benefits only for buyers & Agndal and Nilsson (2008) \\
\hline
\end{tabular}

Source: Survey data (2015).

Kulmala (2004) explained that one of the obstacles to interorganizational relations is the disagreement over sharing benefits. Companies tend to not wish to cooperate and share cost information when the benefits are not shared fairly. Kajüter and Kulmala (2005) stated that there is no general rule on how savings generated by the inter-relationships should be shared, which is justified by the fact that situations vary from case to case. Christopher (1998) pointed out that this does not mean that the benefits should always be shared equally, but those involved are in agreement and satisfied with the benefits for each one of them.

Nicolini et al. (2000) emphasized that market prices of products arising from inter-relationships can be difficult to determine. According to the authors, for some products, such as commodities, it is easier to determine prices charged to consumers, because prices are set by the market; however, companies may have difficulty in determining the prices of other products.

Problems and difficulties are expected in interorganizational networks; thus, conflicts between parties are a normal component for the development of the network. However, according to Arino and De La Torre (1998), constant conflicts can lead to the termination of the relationship. Lui (2009) explained that relationships can end after the stress caused by conflicts, even if the relationship started based on trust, good will of the parties, financial resources and commitment.

Agndal and Nilsson (2008) stated that an open-book accounting policy is not necessarily something implemented by the buyer, exclusively for the benefit of the buyer. The authors explained that one can find open books in a collaborative environment, where they are recognized as beneficial effects for both parties. Thus, suppliers should be aware that sharing of information in order to conduct a strategic cost management can bring benefits to the whole chain. If it is not perceived by suppliers, it can lead to a lack of interest in entering into inter-relationships, a fact seen as a barrier to Interorganizational Cost Management.

\subsection{Lack of Trust between Companies}

Cooper and Slagmulder (1999) explained that trust is the basis of IOCM as it allows greater interaction between the agents involved in the network. The authors agree that factors may favor or inhibit the formation of 
partnerships between companies, and trust is one of the most important factor (Cooper \& Slagmulder, 1999; Kajüter \& Kulmala, 2005; Souza \& Rocha, 2009).

Lack of trust can trigger a number of factors that inhibit the IOCM practice. Table 7 shows the inhibiting factors relative to lack of trust between companies.

Table 7. Inhibitors relative to the lack of trust between companies

\begin{tabular}{|c|c|}
\hline Inhibiting factors & Authors \\
\hline $\begin{array}{l}\text { Lack of interest on the part of the partner companies in } \\
\text { sharing information }\end{array}$ & $\begin{array}{l}\text { Cooper and Slagmulder (2003); LaLonde and Pohlen (1996); Kulmala et al. } \\
\text { (2002); Kulmala (2004) }\end{array}$ \\
\hline $\begin{array}{l}\text { Lack of interest from suppliers in using Open Book } \\
\text { Accounting }\end{array}$ & Caker (2008); Windolph and Moeller (2012); Mcivor (2001); Munday (1992) \\
\hline Uncertainty about the relationship with partners & Barney and Hesterly (1996) \\
\hline Lack of trust among the partners in IOCM & Dekker (2004) \\
\hline
\end{tabular}

Source: Survey data (2015).

Cooper and Slagmulder (2003) explained that cooperation between companies must seek the reduction of the total cost and, thus, seek to increase corporate profits. The networks of buyers and suppliers must be governed based on trust and great sharing of information. However, companies may be reluctant to share information, mainly driven by uncertainties.

LaLonde and Pohlen (1996) explained that the reluctance to share cost information can be a significant obstacle for the determination of supply chain costs. As a result, companies may continue to behave independently, and thus inadvertently increase costs throughout the supply chain.

Information sharing should be bidirectional and lack of interest in sharing information by a member of the chain can be a barrier to interorganizational relationships (Kulmala et al., 2002).

Windolph and Moeller (2012) explained that there may be lack of interest from suppliers in sharing information with members of the chain. According to the authors, vendors may refuse the idea of using open book accounting for fear that buyers use the data to increase the pressure on their profit margins.

Barney and Hesterly (1996) stated that the greater the uncertainty in the agreements and partnerships between companies, the more control mechanisms, such as the use of contracts, are required, which increases the complexity of relationships. The authors explained that companies can adopt governance measures and establish hierarchical structures in order to settle possible disagreements.

Dekker (2004) pointed out that control mechanisms help to reduce uncertainties and risks, so that they enhance trust between the companies. Finally, the author stated that companies should look for ways to ensure the stability and continuity of the alliance in the future in order to prevent lack of trust among companies from being a barrier to strategic cost management.

\section{Conclusions and Recommendations}

By acting collaboratively with members of the supply chain in order to reduce the total cost of the product, significant advantages ca be gained against competing chains. In fact, the relationship network of companies can play a key role in their survival and development.

There are many advantages about forming partnerships between companies; however, there are numerous difficulties and factors that hinder and inhibit relations aimed at reducing costs in the chain. Nicolini et al. (2000) and Norek and Pohlen (2001) explained that the for approaches to Interorganizational Cost Management to be successful, the internal development of companies has to take place, such as knowledge and understanding of costs, understanding of organizational culture and education and training of employees. For the authors, companies must first overcome internal barriers and then later make efforts to take advantage of external cost management.

When entering into partnerships, companies expect to develop and strengthen in the market. However, when a partnership is unsuccessful, sometimes because managers are not prepared, the involved companies can be disappointed. Pereira et al. (2010) explained that the process of removing or excluding a corporate network can cause discomfort between the parties, among other reasons, due to the cancellation of contracts that may have been signed at the beginning of the partnerships.

As for the identified inhibiting factors, it can be seen that Interorganizational Cost Management is an 
interdisciplinary phenomenon that involves people, corporate culture, technology and processes. It is argued, based on the findings of the present research, that the application of Interorganizational Cost Management practices cannot be seen as a technical approach, only guided by technology and management programs.

As a limitation of the research, the use of works from different sources and in different contexts has allowed the identification of overly generic and comprehensive factors, without a specific look into a particular branch or economic sector.

Finally, suggestions for further research include: a) analysing whether the strategic focus of companies interferes in the decision to enter into strategic alliances; b) conducting research with an interdisciplinary focus, seeking to mitigate the inhibiting factors when they arise in the relationship between companies. In fact, the study related to Interorganizational Cost Management and the challenges posed by this approach are a great opportunity for future research aimed at helping managers to deal with the complex task of managing companies' external costs.

\section{References}

Abbade, E. B. (2005) Cooperação interorganizacional na associação londrinense de empresários supermercadistas e no APL têxtil de Goioerê: Uma análise sob a ótica da Teoria dos Custos de Transação. (Master's thesis, University of Paraná, Curitiba, Brazil). Retrieved from http://zip.net/bksHpw

Agndal, H., \& Nilsson, U. (2008). Supply chain decision-making supported by an open books policy. International Journal of Production Economics, 116(1), 154-167. http://dx.doi.org/10.1016/j.ijpe.2008.08.038

Amato, N. J. (2000). Redes de cooperação produtiva e clusters regionais: Oportunidades para as pequenas $e$ médias empresas (3rd ed.). São Paulo, SP: Atlas.

Arino, A., \& De La Torre, J. (1998). Learning from failure: Towards an evolutionary model of collaborative ventures. Organization Science, 9(3), 306-325. http://dx.doi.org/10.1287/orsc.9.3.306

Axelsson, B., Laage-Hellman, J., \& Nilsson, U. (2002). Modern management accounting for modern purchasing. European Journal of Purchasing \& Supply Chain Management, 8(1), 53-62. http://dx.doi.org/10.1016/S0969-7012(01)00017-X

Barney, J. B., \& Hesterly, W. (1996). Organizational economics: Understanding the relationship between organizations and economic analysis (1st ed.). London, UK: Sage.

Bastl, M., Grubic, T., Templar, S., Harrison, A., \& Fan, I. (2010). Inter-organisational costing approaches: The inhibiting factors. The International Journal of Logistics Management, 21(1), 65-88. http://dx.doi.org/10.1108/09574091011042188

Bohlander, G., Snell, S. A., \& Sherman, A. (2003). Administração de recursos humanos (2nd ed.). São Paulo, SP: Thomson.

Borges-Andrade, J. E. (2002). Desenvolvimento de medidas em avaliação de treinamento. Estudos de Psicologia, 7(1), 31-43. http://dx.doi.org/10.1590/S1413-294X2002000300005

Borin, N., \& Farris, P. (1990). An empirical comparison of direct product profit and existing measures of SKU productivity. Journal of Retailing, 66(3), 297-314. Retrieved from http://digitalcommons.calpoly.edu/mkt_fac/8

Caker, M. (2008). Intertwined coordination mechanisms in interorganisational relationships with dominated suppliers. Management Accounting Research, 19(3), 231-251. http://dx.doi.org/10.1016/j.mar.2008.06.003

Cannon, J. P., \& Homburg, C. (2001). Buyer-supplier relationships and customer firm costs. Journal of Marketing, 65(1), 29-43. http://dx.doi.org/10.1509/jmkg.65.1.29.18136

Carr, C., \& Ng, J. (1995). Total cost control: Nissan and its U.K. supplier partnerships. Management Accounting Research, 6(4), 347-365. http://dx.doi.org/10.1006/mare.1995.1025

Christopher, M. (1998). Logistics and supply chain management: Strategies for reducing cost and improving service (2nd ed.). London, UK: Pitman Publishing.

Cooper, R., \& Slagmulder, R. (1999). Supply chain development for the lean enterprise: Interorganizational Cost Management (1st ed.). Trenton, NJ: The IMA Foundation for Applied Research.

Cooper, R., \& Slagmulder, R. (2003). Interorganizational costing: Part 1. Cost Management, 17(5), 14-21.

Dekker, H. C. (2003). Value chain analysis in interfirm relationships: A field study. Management Accounting Research, 14(1), 1-23. http://dx.doi.org/10.1016/S1044-5005(02)00067-7 
Dekker, H. C. (2004). Control of inter-organizational relationships: Evidence on appropriation concerns and coordination requirements. Accounting, Organizations and Society, 29(1), 27-49. http://dx.doi.org/10.1016/S0361-3682(02)00056-9

Drucker, P. F. (1997). Toward the new organization. Executive Excellence, 14(2), 17-28. http://dx.doi.org/10.1002/lt1.40619970304

Dubois, A. (2003). Strategic cost management across boundaries of firms. Industrial Marketing Management, 32(5), 365-374. http://dx.doi.org/10.1016/S0019-8501(03)00010-5

Ellram, L. M. (1994). A taxonomy of Total Cost of Ownership models. Journal of Business Logistics, 15(1), 171-191.

Ellram, L. M. (2002). Strategic cost management in the supply chain: A purchasing and supply management perspective (1st ed.). Phoenix, AZ: CAPS Research.

Ellram, L. M., \& Siferd, S. P. (1998). Total Cost of Ownership: A key concept in strategic cost management decisions. Journal of Business Logistics, 19(1), 55-84.

Ferrin, B. G., \& Plank, R. E. (2002). Total Cost of Ownership Models: An exploratory study. Journal of Supply Chain Management, 38(3), 18-29. http://dx.doi.org/10.1111/j.1745-493X.2002.tb00132.x

Gareth, B. (2005). Perfecting partnerships. Professional Engineering, 17(21), 34-44.

Gupta, K. M., \& Gunasekaran, A. (2004). Costing in new enterprise environment: A challenge for managerial accounting researchers and practitioners. Managerial Accounting Journal, 20(4), 337-357. http://dx.doi.org/10.1108/02686900510592034

Guth, W., Schmittberger, R., \& Schwarze, B. (1982). An experimental analysis of ultimatum bargaining. Journal of Economic Behavior and Organization, 3(1), 367-388. http://dx.doi.org/10.1016/0167-2681(82)90011-7

Himme, A. (2012). Critical success factors of strategic cost reduction. Metrika, 23(3), 183-210. http://dx.doi.org/10.1007/s00187-012-0157-8

Hitt, M. A., Dancin, M. T., Levitas, E., Arregle, J., \& Borza, A. (2000). Partner selection in emerging and developed market contexts: Resource-based and organizational learning perspectives. Academy of Management Journal, 43(3), 449-467. http://dx.doi.org/10.2307/1556404

Janowicz-Panjaitan, M., \& Noorderhaven, N. G. (2009). Trust, calculation, and interorganizacional learning of tacit knowledge: An organizational roles perspective. Organization Studies, 30(10), 1021-1044. http://dx.doi.org/10.1177/0170840609337933

Kajüter, P., \& Kulmala, H. (2005). Open book accounting in networks: Potencial achievements and reasons for failures. Management Accounting Reserarch, 16(2), 179-204. http://dx.doi.org/10.1016/j.mar.2005.01.003

Kaplan, R. S., \& Anderson, S. R. (2004). Time-Driven Activity-Based Costing. Harvard Business Review, 82(11), 131-138. http://dx.doi.org/10.2139/ssrn.485443

Kulmala, H. (2004). Developing cost management in cutomer-supplier relationships: Three case studies. Journal of Purchasing \& Supply Management, 10(2), 65-77. http://dx.doi.org/10.1016/j.pursup.2004.02.003

Kulmala, H., Paranko, J., \& Uusi-Rauva, E. (2002). The role of cost management in network relationships. $\begin{array}{lllll}\text { International Journal of Production } & \text { Economics, } & 79(1), & 33-43 .\end{array}$ http://dx.doi.org/10.1016/S0925-5273(00)00061-X

Lalonde, B. (2003). Three problems that linger. Supply Chain Management Review, 7(2), 17-28.

Lalonde, B., \& Pohlen, T. (1996). Issues in Supply Chain Costing. The International Journal of Logistics Management, 7(1), 1-11.

Lin, B., Collins, J., \& Su, R. K. (2001). Supply chain costing: An activity-based perspective. International Journal $\begin{array}{lllll}\text { of Physical Distribution \& Logistics Management, } & 31(9), & \text { 702-713. }\end{array}$ http://dx.doi.org/10.1108/EUM0000000006286

Lopes, P. C. B., Stadler, C. C., \& Kovaleski, J. L. (2003). Gestão da mudança organizacional. Revista Publicatio: Ciências Humanas, Linguística, Letras $e$ Artes, 11(1), 51-57. http://dx.doi.org/10.5212/publ.humanas.v11i1.491

Lui, S. S. (2009). The roles of competence trust, formal contract, and time horizon in interorganizational learning. Organization Studies, 30(4), 333-353. http://dx.doi.org/10.1177/0170840608101139 
Mcivor, R. (2001). Lean supply: The design and cost reduction dimensions. European Journal of Purchasing and Supply Management, 7(4), 227-242. http://dx.doi.org/10.1016/S0969-7012(01)00004-1

Möller, K., Windolph, M., \& Isbruch, F. (2011). The effect of rational factors on open-book accounting and inter-organisational cost management in buyer-supplier partnerships. Journal of Purchasing \& Supply Management, 17(2), 121-131. http://dx.doi.org/10.1016/j.pursup.2011.01.002

Mouritsen, J., \& Thrane, S. (2006). Accounting, network complementarities and the development of inter-organisational relations. Accounting, Organizations and Society, 31(3), 241-275. http://dx.doi.org/10.1016/j.aos.2005.04.002

Munday, M. (1992). Accounting cost data disclosure and buyer-supplier partnerships: A research note. Management Accounting Research, 3(3), 245-250. http://dx.doi.org/10.1016/S1044-5005(92)70014-6

Nicolini, D., Tomkins, C., Holti, R., Oldman, A., \& Smalley, M. (2000). Can Target Costing be applied in the construction industry? Evidence from two case studies. British Journal of Management, 11(4), 303-324. http://dx.doi.org/10.1111/1467-8551.00175

Norek, C. D., \& Pohlen, L. (2001). Cost knowledge: A foundation for improving supply chain relationships. $\begin{array}{lllll}\text { International Journal of Logistics } & \text { Management, } & \text { 12(1), } & \text { 37-51. }\end{array}$ http://dx.doi.org/10.1108/09574090110806217

Ojala, M., \& Hallikas, J. (2007). Financial decision risks in supplier networks. Managing Supply Chain Risks, 8(2), 80-91. http://dx.doi.org/10.1080/16258312.2007.11517184

Pereira, B. A. D., Alves, J. N., \& Silva, P. E. (2010). Olado obscuro dos relacionamentos interorganizacionais: Por que as empresas saem dos processos cooperativos? Espacios, 31(4), 25-27.

Porter, M. (1980). Estratégia competitiva: Técnicas para análise da indústria e da concorrência (5th ed.). Rio de Janeiro, RJ: Campus.

Ramos, M. M. (2004). Interaction between management accounting and supply chain management. Supply Chain Management: An International Journal, 9(2), 134-138. http://dx.doi.org/10.1108/13598540410527033

Seal, W., Cullen, J., Dunlop, A., Berry, T., \& Ahmed, M. (1999). Enacting a European supply chain: A case study on the role of management accounting. Management Accounting Research, 10(1), 303-322. http://dx.doi.org/10.1006/mare.1999.0105

Souza, B. C., \& Rocha, W. (2009). Gestão de Custos Interorganizacionais: Ações coordenadas entre clientes e fornecedores para otimizar resultados (1st ed.). São Paulo, SP: Atlas.

Stapleton, D., Pati, S., Beach, E., \& Julmanichoti, P. (2004). Activity-Based Costing for logistics and marketing. Business Process Management Journal, 10(5), 584-597. http://dx.doi.org/10.1108/14637150410559243

Thomson, J., \& Gurowka, J. (2005). Sorting out the clutter. Strategic Finance, 87(2), $27-33$.

Tomkins, C. (2001). Interdependencies, trust and information in relationships, alliances and networks. Accounting, Organizations and Society, 26(2), 161-191. http://dx.doi.org/10.1016/S0361-3682(00)00018-0

Waeytens, D., \& Bruggeman, W. (1994). Barriers to successful implementation of ABC for continuous improvement: A case study. International Journal of Production Economics, 36(2), 39-52. http://dx.doi.org/10.1016/0925-5273(94)90147-3

Williamson, O. E. (1985). The economic institutions of capitalism (5th ed.). New York, NY: Free Press.

Wincent, J. (2008). An exchange approach on firm cooperative orientation and outcomes of strategic multilateral network participants. Group Organization Management, 33(3), 303-329. http://dx.doi.org/10.1177/1059601108318184

Windolph, M., \& Moeller, K. (2012). Open-book accounting: Reason for failure of inter-firm cooperation? Management Accounting Research, 23(1), 47-60. http://dx.doi.org/10.1016/j.mar.2011.07.001

\section{Copyrights}

Copyright for this article is retained by the author(s), with first publication rights granted to the journal.

This is an open-access article distributed under the terms and conditions of the Creative Commons Attribution license (http://creativecommons.org/licenses/by/3.0/). 